Participatory Educational Research (PER)

Vol. 1(2), pp. 95-105, December, 2014

Available online at http://www.partedres.com

ISSN: 2148-6123

http://dx.doi.org/(coming soon)

\title{
An Examination of Secondary School Students' Academic Achievement in Science Course and Achievement Scores in Performance Assignments with Regard to Different Variables: A Boarding School Example
}

\author{
Aykut Emre Bozdoğan*
}

Giresun University, Faculty of Education, Giresun, Turkey

Esra Günaydın

Giresun University, Institute of Science, Giresun, Turkey

\begin{abstract}
Alperen Okur
Giresun University, Institute of Science, Giresun, Turkey

Article history

Received:

09.09.2014

Received in revised form: 07.10.2014

Accepted:

09.10.2014

Key words:

Science course, performance task, boarding student

The aim of the study is to explore the academic achievement and performance tasks of students studying in a regional primary boarding school in science course with regard to different variables. The study was carried out via survey method and total 96 students, 57 of them boarding students and 39 of them non-boarding students studying in the 5th, 6th, and 7 th grades in a regional primary boarding schools, participated in the study. The data of the study was obtained from the academic performance grade point average which the students got from three different exams in Science course and performance grade point average the students got from two different performance assignments (preparing a poster). MANOVA and correlation analysis were used for the statistical analysis of the data which were collected to seek answers for the sub-problems stated within the general framework of the research. The findings revealed that there is not a significant difference between the grade levels and the students' academic achievement scores and performance scores in science course, whereas a significant difference was found between the gender variable and performance scores, which was in favour of females. This result suggests that female students were more successful than male students when compared to performance assignments. Moreover, a meaningful difference was detected in favour of non-boarding students with regard to their academic achievement in science course and their grades in performance assignments. Finally, it was found that there was a moderate positive correlation between the students' academic achievement scores in science course and performance scores in performance assignments.
\end{abstract}

\footnotetext{
Correspondence: aykutemre@gmail.com
} 


\section{Introduction}

The traditional education program changed in Turkey in 2005-2006 academic year and since then, an education program based on constructivism has been adopted. In addition to the assessment and evaluation techniques which are oriented for product, alternative assessment and evaluation techniques which assess both the product and the process together have gained importance in the new curriculum which is based on constructivism. Both the product and the process are focused on during the process of evaluation of student performances within the context of alternative assessment and evaluation techniques and thanks to performance assessment, a teacher has an opportunity to identify clearly how students understand knowledge and apply it (Bahar et. al., 2010). One of the performance assessment methods is performance tasks (Secer, 2010). Performance tasks, one of the alternative assessment and evaluation techniques and used in performance assessment (Öztürk, 2010), are activities which consider students' individual differences and give opportunities to the students to apply the skills and knowledge they have to the problem situations they experience (Ar1, 2002; MEB, 2004). Moreover, performance tasks are activities which enable students to use their creativity and make them active participants (Uzoğlu et. al., 2013). In the renewed education program, it has been considered appropriate that students are required to prepare performance tasks in each lesson to develop their research and thinking skills and assess their learning process (Y1lmaz \& Benli, 2011). Talking, singing, drawing a picture, making deductions from a map, preparing a poster, brochure, leaflet about a specific topic, writing a play, and doing an experiment can be given as examples of performance tasks (Kırılmazkaya, Keçeci \& Kırbağ Zengin, 2011). In order to apply performance tasks, students must have opportunities to actualize research and assignments in their real lives (Adanal1, 2008). When compared from these aspects, it is clear that students differ from each other regarding the opportunities they have. This difference is specifically experienced in regional boarding schools.

Regional primary boarding schools are the primary schools which are established for the purpose of meeting the basic educational needs of the children who have reached the age of compulsory education but who live in the rural areas which have less and scattered population such as village, fields, or a nomad camping site and do not have easy access to education close to their homes. Besides receiving education in these schools, students are provided with opportunities such as accommodation, health care, school expenses, and food. These schools were first opened as regional village schools in villages in 1942 and they turned into regional primary boarding schools in time (MEB, 2003). In 2012-2013 academic year, $5^{\text {th }}, 6^{\text {th }}, 7^{\text {th }}$, and $8^{\text {th }}$ grade students were admitted to Regional Primary Boarding Schools. $1^{\text {st }} 2^{\text {nd }}, 3^{\text {rd }}$, and $4^{\text {th }}$ grade students who used to study in these schools were then provided transportation to go to schools close to their homes. With this change, Regional Primary Boarding Schools were called Regional Secondary Boarding Schools (Official Gazette, 2012)

Regional Primary Boarding Schools (YİBOs) fulfil very important functions in the regions where they are located. Specifically, they undertake considerably important missions regarding students' personal development, keeping up with the changing world, and providing social and cultural development of their regions as well as meeting their own cultures and the era (Şenol \& Y1ldı, 2009). Although boarding schools try to provide education opportunities for the children living in small settlements and in the regions with scattered population, it is considered that because children live far way from their families and experience adaptation problems, these will have an effect on their academic achievement and attitudes towards school. 
The study which is carried out within this context aims at examining and detecting the relationship between the academic achievement and performance assignment achievement scores of students studying in a regional secondary boarding school in science course with regard to different variables. The study sought answers to the following questions:

(1) Is there a relationship between the students' academic achievement in science course and performance assignment achievement scores which they take within the context of this course?

(2) Is there a relationship between the students' genders, grade levels and being a boarding or non-boarding student and their academic achievement in science course and performance assignment achievement scores which they take within the context of this course?

\section{Method}

\section{Research Method}

In the research, survey method, one of the quantitative research methods, was used. This method is conducted to shed light on the event, to make evaluations in line with standards, and to reveal the possible relationship between the events. The main purpose of such research is to identify and explain the case which is examined in detail (Çepni, 2012). This method was chosen in the study because the relationship between the students' academic achievement scores which they got from the science course and their academic achievement scores they got from the performance assignment in the same course was explored regarding different variables.

\section{The population of the Study}

The research was carried out in a regional secondary boarding school located in Giresun in the first term of 2012-2013 academic year. Total 96 students, 57 boarding and 39 non-boarding, participated in the study.

\section{Data Collection Tool}

The research data was obtained from the academic performance grade point average which the students got from the three different exams in science course and performance grade point average the students got from two different performance assignments (preparing a poster). Students' academic achievement scores and performance assignment scores were assessed out of 100. Students' performance tasks were evaluated by two different researchers working independently of each other via analytical rubric. Analytical rubric consists of 5 different sections and each section is 20 point. These sections in the rubric consisted of content, appearance, originality, use of material/ materials' in accordance with each other, and time.

The content of the academic achievement tests and the performance tasks assigned were organized according to the grade levels and they were presented in Table 1. 
Table 1. Information about the content of academic achievement tests and performance assignments

\begin{tabular}{|c|c|c|c|c|c|c|}
\hline ڤ⿱艹 & 离 & Unit & Subject & 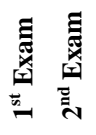 & 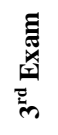 & $\begin{array}{l}\text { Performance Assignments } \\
\text { (Poster preparation subjects) }\end{array}$ \\
\hline \multirow{3}{*}{ 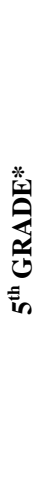 } & 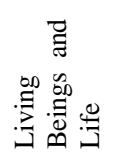 & $\begin{array}{l}\text { Let's solve the } \\
\text { puzzle of our body }\end{array}$ & $\begin{array}{l}\text { a) Nutrition and balanced diet } \\
\text { b) Digestion and Excretion of food } \\
\text { c) Unhealthy agents }\end{array}$ & & & \multirow{3}{*}{$\begin{array}{l}\text { a) Nutrient content of food and their } \\
\text { functions } \\
\text { b)Digestive system organs and their } \\
\text { functions organ } \\
\text { c)Excretory system organs and their } \\
\text { functions } \\
\text { c) Kinds of teeth and their functions } \\
\text { d) Unhealthy agents and their effects on } \\
\text { the body } \\
\text { e)Water cycle and the events occurring at } \\
\text { that moment } \\
\text { f)The difference between temperature and } \\
\text { heat } \\
\text { g) Contact and non-contact forces }\end{array}$} \\
\hline & 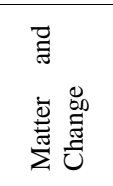 & $\begin{array}{l}\text { Changes in matter } \\
\text { and its recognition }\end{array}$ & $\begin{array}{l}\text { a) Water turns into different states } \\
\text { b) Heat and temperature } \\
\text { c) Heat effects materials } \\
\text { d)Distinctive characteristics of matter }\end{array}$ & & & \\
\hline & 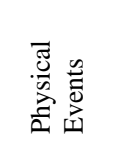 & Force and motion & $\begin{array}{l}\text { a) Contact and non-contact forces } \\
\text { b) Let's learn the magnets } \\
\text { c)Friction force }\end{array}$ & & & \\
\hline \multirow{3}{*}{ 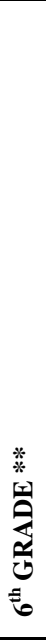 } & 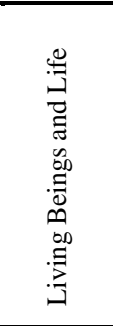 & $\begin{array}{l}\text { Reproduction, } \\
\text { growth, and } \\
\text { development } \\
\text { living beings }\end{array}$ & $\begin{array}{l}\text { a) The fundamentals of living being: } \\
\text { Cell } \\
\text { b) Human reproduction, growth, and } \\
\text { development } \\
\text { c) I am not a child anymore } \\
\text { d)Animal reproduction, growth, and } \\
\text { development } \\
\text { e) Reproduction of flowering plants } \\
\text { f) Plant germination, growth, and } \\
\text { development }\end{array}$ & & & \multirow{3}{*}{$\begin{array}{l}\text { a)The structure of plant and animal cell, } \\
\text { their organelles and functions } \\
\text { b) Characteristics of egg and sperm cells } \\
\text { c) Female and male reproductive organs } \\
\text { and their functions } \\
\text { d) Physical and psychological changes } \\
\text { that occur with the females and females } \\
\text { during puberty } \\
\text { e) Features of vertebrates and } \\
\text { invertebrates such as reproduction and } \\
\text { baby animal care } \\
\text { f) Reproductive organs of flowering } \\
\text { plants, pollination and fertilization } \\
\text { g) Seeds of different colours and shapes } \\
\text { h) Speed of various vehicles } \\
\text { i) Differences between mass and weight } \\
\text { j) Features of atom, element, and } \\
\text { compounds }\end{array}$} \\
\hline & 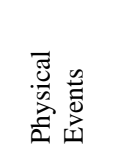 & Force and Motion & $\begin{array}{l}\text { a) Speed in our life } \\
\text { b) Let's discover force } \\
\text { c) Forces are in charge } \\
\text { d) Weight is a force }\end{array}$ & & & \\
\hline & 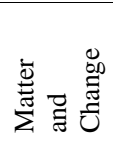 & $\begin{array}{l}\text { Changes in matter } \\
\text { and its recognition }\end{array}$ & $\begin{array}{l}\text { a) Particles that make up matter } \\
\text { b) Elements and their compounds } \\
\text { c) Physical and chemical change } \\
\text { d) States of matter and its structure }\end{array}$ & & & \\
\hline \multirow{3}{*}{ 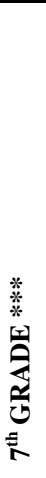 } & 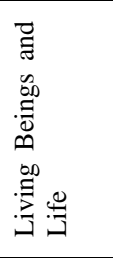 & $\begin{array}{l}\text { Systems in our } \\
\text { body }\end{array}$ & $\begin{array}{l}\text { a)Digestive system and health of } \\
\text { digestive system } \\
\text { b)Excretory system discharges wastes } \\
\text { from our body } \\
\text { c)Controlling-regulating systems } \\
\text { d) Sense organs } \\
\text { e)Health of the systems in our body and } \\
\text { organ donation }\end{array}$ & & & \multirow{3}{*}{$\begin{array}{l}\text { a) Functions of digestive system organs } \\
\text { b) Excretory system organs and their } \\
\text { functions } \\
\text { c)Nervous system organs and their } \\
\text { functions } \\
\text { d) Regulatory system organs and their } \\
\text { functions } \\
\text { e)Sense organs and their functions } \\
\text { f) Kinds of springs, their features and } \\
\text { weight-stretching graphic } \\
\text { g) Features of kinetic and potential energy } \\
\text { and energy conversion (the process of } \\
\text { changing one form of energy to another) } \\
\text { h) Types of simple machine and their use }\end{array}$} \\
\hline & 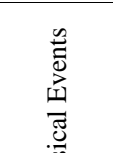 & Force and Motion & $\begin{array}{l}\text { a) Let's learn the springs } \\
\text { b) Work and force } \\
\text { c)Simple machines in our life } \\
\text { d) Energy and friction force }\end{array}$ & & & \\
\hline & $\stackrel{\infty}{a}$ & $\begin{array}{l}\text { Electricity in our } \\
\text { life }\end{array}$ & $\begin{array}{l}\text { e) Electrification } \\
\text { f) Electric current }\end{array}$ & & & \\
\hline
\end{tabular}




\footnotetext{
$* 5^{\text {th }}$ grade exam questions and grading; $1^{\text {st }}$ Exam ( 23 point matching questions, 17 point showing on the figure questions , 20 point truefalse questions, and 40 point multiple choice questions).

$2^{\text {nd }}$ Exam (20 point classification questions, 10 point open -ended questions, 10 point demonstrating on the figure questions, 20 point truefalse questions, and 10 point fill in the blanks questions, and 30 point multiple choice questions); $3^{\text {rd }}$ Exam (100 point multiple choice questions)

$* * 6^{\text {th }}$ grade exam questions and grading; $1^{\text {st }}$ Exam ( 30 point classification questions, 30 point showing on the figure questions, 20 point true-false questions, and 20 point multiple choice questions) $2^{\text {nd }}$ Exam (28 point open-ended questions, 20 point true-false questions, 12 point fill in the blanks questions and 40 point multiple choice questions) ; $3^{\text {rd }}$ Exam (100 point multiple choice questions).

**** $7^{\text {th }}$ grade exam questions and grading; $1^{\text {st }}$ Exam ( 20 point matching questions, 30 point showing on the figure questions, 20 point true-false questions, and 30 point multiple choice questions).

$2^{\text {nd }}$ Exam (10 point drawing graph questions , 18 point open-ended questions, 20 point true-false questions, 20 point fill in the gaps questions, and 32 point multiple choice questions; $3^{\text {rd }}$ Exam (100 point multiple choice questions).
}

\section{Data Analysis}

MANOVA and correlation analysis were used to determine the differences between the independent variables within the context of statistical analysis of the data obtained from the subproblems whose answers were sought within the framework of general purpose of the research. The data related to numerical developments were presented in tables and interpreted. Moreover, whether there was a significant difference between the independent variables or not was tested at the level of $\alpha=.05$.

\section{Findings}

The correlation between the academic performance grade point average the students who participated in the study got from the science course exams and their performance assignment grade point average and the gender was analysed and it was presented in Table 2.

Table 2. Correlation analysis related to students' academic achievement scores in science course and performance assignment achievement scores

\begin{tabular}{llllll}
\hline Variable & $\mathbf{N}$ & $\bar{X}$ & $\mathbf{S}$ & $\mathbf{r}$ & $\mathbf{p}$ \\
\hline $\begin{array}{l}\text { Academic achievement score } \\
\text { Performance assignment }\end{array}$ & 96 & 55.07 & 10.66 & & \\
achievement score & 96 & 79.08 & 16.21 & 0.471 & $\mathbf{0 0 0}$ \\
\hline
\end{tabular}

When Table 2 is examined, there is a significant difference between the students' academic achievement scores in science course and performance assignment achievement scores ( $\mathrm{r}=.471$, $\mathrm{p}=.000, \mathrm{p}<.05)$. When the direction and magnitude of this relationship is examined, it is revealed that there is a moderate positive relationship.

Table 3. MANOVA results related to the students' genders and students' academic performance grade point average from the exams in science course and performance assignment grade point average

\begin{tabular}{llllllll}
\hline Variable & Gender & $\mathbf{N}$ & $\bar{X}$ & $\mathbf{S}$ & sd & F & p \\
\hline \multirow{3}{*}{ Exam Scores } & Male & 51 & 55.00 & 15.39 & & & \\
& Female & 45 & 55.15 & 17.27 & $1-94$ & .002 & .963 \\
& Total & 96 & 55.07 & 16.21 & & & \\
\hline \multirow{3}{*}{ Performance Assignment Scores } & Male & 51 & 76.07 & 10.51 & & & \\
& Female & 45 & 82.48 & 9.89 & $1-94$ & 9.393 & $\mathbf{. 0 0 3}$ \\
& Total & 96 & 79.08 & 10.66 & & & \\
\hline
\end{tabular}


A significant difference was detected between the students' academic achievement grade point average in science course and performance assignment achievement grade point average and the gender variable $\left[\left(\lambda_{\text {Wilks' Lambda }}\right)=0.885, \mathrm{~F}_{(2-93)}=6.041, \mathrm{p}=0.003, \mathrm{p}<.05\right]$. This finding demonstrates that the points which will be obtained from the linear components composed of students' academic achievement scores in science course and performance assignment achievement scores change depending on the gender. When Table 3 was examined in this context, it was found that academic achievement grade point average of male students in the exams in science course is $(\bar{x}=55.00)$ and the females' grade point average is $(\bar{x}=55.15)$. It was viewed that there was not a meaningful difference between the students' academic achievement grade point average $\left[F_{(1-94)}=0.002\right.$, p>.05]. Therefore, this result reveals that the academic performances of female and male students are equal. However, the academic performance grade point average of male students in performance assignments which they took within the context of science course was determined to be $(\bar{x}=76.07)$ and the academic performance grade point average of female students was $(\bar{x}=$ 82.48). It was discovered that there was a significant difference between the performance assignment scores of the students which they took within the context of science course in favour of female students $\left[\mathrm{F}_{(1-94)}=-9.393, \mathrm{p}<.05\right]$. It can be stated in this context that female students are more successful than male students regarding performance assignments.

The relationship between the students' academic achievement grade point average in the exams in science course and performance assignment grade point average and their being boarding students were examined and presented in Table 4.

Table 4. MANOVA results related to the students' being boarding and students' academic performance grade point average from the exams in science course and performance assignment grade point average

\begin{tabular}{|c|c|c|c|c|c|c|c|}
\hline Variable & Being a boarding student & $\mathbf{N}$ & $\bar{X}$ & $\mathbf{S}$ & sd & $\mathbf{F}$ & $\mathbf{p}$ \\
\hline \multirow{3}{*}{ Exam Scores } & Boarding student & 57 & 50,21 & 13,94 & \multirow{3}{*}{$1-94$} & \multirow{3}{*}{14.391} & \multirow{3}{*}{.000} \\
\hline & Non-boarding student & 39 & 62,17 & 16,83 & & & \\
\hline & Total & 96 & 55,07 & 16,21 & & & \\
\hline \multirow{3}{*}{$\begin{array}{l}\text { Performance } \\
\text { Assignment Scores }\end{array}$} & Boarding student & 57 & 77,12 & 10,83 & \multirow{3}{*}{$1-94$} & \multirow{3}{*}{4.934} & \multirow{3}{*}{.029} \\
\hline & Non-boarding student & 39 & 81,94 & 9,86 & & & \\
\hline & Total & 96 & 79,08 & 10,66 & & & \\
\hline
\end{tabular}

A significant difference was detected between the students' academic achievement grade point average in science course and performance assignment achievement grade point average and being boarding or non-boarding students $\left[\left(\lambda_{\text {Wilks' }}\right.\right.$ Lambda $\left.)=0.864, \mathrm{~F}_{(2-93)}=7.333, \mathrm{p}=0.001, \mathrm{p}<.05\right]$. This finding shows that the points which will be obtained from the linear components composed of students' academic achievement scores in science course and performance assignment achievement scores change depending on receiving education as a boarding student.

When Table 4 was examined within this context, it was found that academic achievement grade point average of boarding students from the exams in science course is $(\bar{x}=50.21)$, and nonboarding students' grade point average is determined to be $(\bar{x}=62.17)$. It was revealed that there was a significant difference in favour of non-boarding students regarding the differences between 
their academic achievement grade point averages $\left[F_{(1-94)}=14.391, p<.05\right]$. This finding demonstrates that the students who continue their education near their families are more successful in science course than the boarding students.

In addition to this, it was found that the performance assignment academic achievement grade point averages of boarding students were $(\bar{x}=77.12)$ whereas the academic achievement grade point averages of non-boarding students were determined to be $(\bar{x}=81.94)$.

Moreover, it was revealed that there was a significant difference in favour of non-boarding students with regard to the differences in performance assignment scores which they took within the context of science course $\left[\mathrm{F}_{(1-94)}=4.934, \mathrm{p}<.05\right]$. It can be stated within this context that the students who continue their education near their families are more successful in performance assignments.

The relationship between the students' academic achievement grade point averages from the exams in science course and performance assignment grade point averages and their grade levels were examined and presented in Table 5.

Table 5. MANOVA results related to the students' grade levels and students' academic performance grade point averages from the exams in science course and performance assignment grade point averages

\begin{tabular}{|c|c|c|c|c|c|c|c|}
\hline Variable & Grade Level & $\mathbf{N}$ & $\bar{X}$ & $\mathbf{S}$ & sd & $\mathbf{F}$ & $\mathbf{p}$ \\
\hline \multirow{4}{*}{ Exam Scores } & $5^{\text {th }}$ Grade & 24 & $\overline{52.66}$ & 17.55 & \multirow{4}{*}{$2-93$} & \multirow{4}{*}{0.417} & \multirow{4}{*}{.660} \\
\hline & $6^{\text {th }}$ Grade & 34 & 55.11 & 16.27 & & & \\
\hline & $7^{\text {th }}$ Grade & 38 & 56.55 & 15.53 & & & \\
\hline & Total & 96 & 55.07 & 16.21 & & & \\
\hline \multirow{4}{*}{$\begin{array}{l}\text { Performance Assignment } \\
\text { Scores }\end{array}$} & $5^{\text {th }}$ Grade & 24 & 74.83 & 11.04 & \multirow{4}{*}{$2-93$} & \multirow{4}{*}{2.713} & \multirow{4}{*}{.072} \\
\hline & $6^{\text {th }}$ Grade & 34 & 79.97 & 11.07 & & & \\
\hline & $7^{\text {th }}$ Grade & 38 & 80.97 & 9.53 & & & \\
\hline & Total & 96 & 79.08 & 10.66 & & & \\
\hline
\end{tabular}

There is not a significant difference between the students' academic achievement grade point averages from the exams in science course and performance assignment grade point averages and their grade levels $\left[\left(\lambda_{\text {Wilks' Lambda }}\right)=0.944, \mathrm{~F}_{(4-184)}=1.350, \mathrm{p}=0.253, \mathrm{p}>.05\right]$. This finding indicates that the points which will be obtained from the linear components composed of students' academic achievement scores in science course and performance assignment achievement scores do not change depending on grade levels. When Table 5 was examined within this context, it was found that academic achievement grade point averages of $5^{\text {th }}$ grade students from the exams in science course is $(\bar{x}=52.66), 6^{\text {th }}$ grade students' grade point average is $(\bar{x}=55.11)$ and the grade point averages of the students studying in Grade 7 is determined to be $(\bar{x}=56.55)$. Although students' academic achievement increases with an increase in their grade levels, it is found that this rise was not at a significant level $\left[\mathrm{F}_{(2-93)}=0.417, \mathrm{p}>.05\right]$. Moreover, it was determined that the performance assignment achievement grade point averages of the students studying in the $5^{\text {th }}$ grade was $(\bar{x}$ $=74.83)$, it was $(\bar{x}=79.97)$ for the students' studying in the $6^{\text {th }}$ grade, and the grade point averages 
were $(\bar{x}=80.97)$ for the $7^{\text {th }}$ grade students. Although students' performance assignment scores increase with an increase in their grade levels, it is revealed that this increase was not at a significant level $\left[\mathrm{F}_{(2-93)}=2.713, \mathrm{p}>.05\right]$.

\section{Results and Discussion}

As a result of the study, a significant relationship was identified between the students' academic achievement scores in science course and performance assignment achievement scores (Table 2). When the direction and magnitude of this relationship was examined, a positive relationship at a moderate level was determined. When relevant literature is reviewed, it is revealed that there is a positive relationship between the students' academic achievement and their state of doing the assignments and their attitudes towards performance assignments (Çelik \& Aktürk, 2009, Gedik \& Orhan, 2013; Gür, 2002; Kumandaş \& Kutlu, 2010; Uzoğlu et. al., 2013). It can be stated that the findings of this study which was conducted within this context show parallelism with the literature. Another result in the study is the relationship between the gender variable and academic achievement and performance assignment achievement. For that purpose, it was discovered that there was not a significant difference between the students' academic achievement in science course and gender; however, it was found that there was a significant difference in favour of female students regarding their scores in performance assignment which they took within the context of science course (Table 3). This finding reveals that regarding performance tasks, female students are more successful than male students. It was stated in the literature that unlike male students, female students have positive attitudes towards the assignments given at a significant level and they also exhibited more positive attitudes than males. The reason for this is that female students are more disciplined, dutiful, submissive and organized(Hong, 1999, Yeşilyurt, 2006) and it might also result from the fact that female students' physical/kinaesthetic and interpersonal/social intelligence points are higher that male students (Pekdemir \& Akyol, 2011). Another study conducted in boarding schools revealed that female students exhibited more positive attitudes towards school than male students and they were more compatible than boys (Buckner, Bassuk \& Weinreb, 2001; Coşkun, 2004; Çetinkaya, 2013; Lucia et al., 2000; Wentzel, 1997). The reason for this is that there are still families living in the villages and who are still against sending their daughters to school and female students consider boarding schools as the only opportunity and chance to receive education (Çetinkaya ve Gelişli, 2014). It can be considered that the female students' being more successful in performance assignments than males may have resulted from these facts. The findings of the study revealed that the higher the grade levels got, the higher academic achievement scores in science course and performance assignment scores students had ; however, it was determined that the difference was not at a significant level (Table 5). This result demonstrates that the understanding level of science course which is described as abstract and which students have mostly difficulty in understanding has increased due to the grade levels and thus increasing age. The other studies conducted reveal that as the grade levels increase, there is an increase in students' performance of doing homework and students do their homework more consciously as they progress through the grade levels (Cooper, Robinson \& Patall, 2006; Gedik \& Orhan, 2013).

The most important finding in the research is the relationship between the academic achievement in science course and performance assignment achievement scores of the boarding students and 
the students who receive education near their families. Within this framework, it was discovered that there was a significant difference in favour of non-boarding students regarding both their academic achievement in science course and performance assignment achievement scores (Table 4). In other words, it can be stated that the students who continue their education near their families are more successful both in science course and performance assignments which they took within the context of science course. When literature is examined, it is found that unlike other students, boarding students have more difficulty in adapting to school due to their being far away from their families and lack of interest from their families (Ak \& Say1l, 2006; Barth et. al., 2004; Kazu \& Aşkın, 2011; Küçük \& Arıkan, 2005), their level of readiness is low and this results in academic failure (Inal, 2009). It was found in the other studies conducted that there was a very close parallelism between the students' academic achievement and families' level of interest in a child (Guest \& Biasini, 2001; Halıc1, 2005; Pettit, Bates \& Dodge, 1997; Wentzell, 1997) and it was found that the performance of students studying in boarding schools were low when compared to other students (Ar1, 2002; Udum, 2012).

In the light of this study and the other studies in literature, giving performance assignments, homework, research projects on any science topics which students like can make contributions to increase students' science achievement. Moreover, teachers can provide more academic support to male students who take performance tasks, so contributions are made to increase their performance task achievement. In addition to this, students in boarding schools do not feel themselves valuable and important and thus they are not expected to adapt to this environment and feel happy and peaceful. However, if students feel themselves valuable, their self-esteem will increase and they will feel happy and peaceful in the environment where they exist and this will make contributions to their academic and social development.

\section{References}

Adanal1, K. (2008). Alternative assessment in Social science: The evaluation of alternative assessment practices in $5^{\text {th }}$ grade Social Science lessons. Çukurova University Institute of Social Sciences, Adana, Turkey. (Unpublished Master Thesis).

Ak, L., \& Sayıl, M. (2006). Three different types of elementary school students' school achievements, perceived social support, school attitudes and behavior adjustment problems. Educational Sciences: Theory \& Practice, 6(2), 293-300.

Ar1, A. (2002). Evaluation of the primary application: Normal, transported and boarding comparison of primary school. National Education, no:153-154.

Bahar, M., Nartgün, Z., Durmuş, S. \& Biçak, B. (2010). Traditional-Complementary Assessment and Evaluation Techniques (4. Press). Anı Publishing, Ankara, Turkey.

Barth, J. M., Dunlap, S. T., Dane, H., Lochman, J. E., \& Wells, K. C. (2004). Classroom environment influnces on aggression, peer relations and academic focus. Journal of School Psychology, 42,115-133.

Buckner, J. C., Bassuk, E. L., \& Weinreb, L. F. (2001). Predictors of academic achievement among homeless and low-income housed children. Journal of Scholl Psychology, 39(1), 45-69.

Cooper, H., Robinson, J. C. \& Patall, E. A. (2006). Does homework improve academic achievement? A synthesis of research, 1987-2003. Review of Educational Research, 76, 162. 
Coşkun, L. (2004). The Relationship between academic achievements, the social support received, attitude towards school and behavior-adjustment problems in boarding, bussing and "normal" primary school students. Hacettepe University, Institute of Social Sciences, Ankara, Turkey. (Unpublished Master Thesis).

Çelik, S. \& Aktürk, Z. (2009). An attempt to increase student performance in a classical classroom setting: Effects of seating arrangement and doing homeworks. National Education, 181, $37-43$.

Çepni, S. (2012). Introduction to Research and Project Work. Celepler Printing, Trabzon, Turkey.

Çetinkaya, M. (2013). Regional primary boarding school students' views on the functioning of their schools: Example of Kahramanmaraş province. Gazi University, Institute of Educational Sciences, Ankara, Turkey. (Unpublished Master Thesis).

Çetinkaya, M. \& Gelişli, Y. (2014). Regional primary boarding school students abouth regional primary boarding school function. The Journal of The Industrial Arts Education Faculty of Gazi University, 33, 1-8.

Gedik, M. \& Orhan, S. (2013). Views of the students attending $6^{\text {th }}$ and $7^{\text {th }}$ grades of primary schools on Turkish subject homeworks. Journal of The Black Sea Studies, 38, 135-148.

Guest, K. C., \& Biasini, F. J. (2001). Middle childhood, poverty, and adjustment: Does social support have an impact? Psychology in the Schools, 38(6), 549-559.

Gür, H. (2002). The effect of doing homework style to academic achievement. Math Activities Symposium, May, Ankara, Turkey.

Halıc1, P. (2005). A study on self-concept and aggressiveness tendencies of children 12-14 age group living together with their families and attending the regional boarding primary schools. Ankara University Institute of Science, Ankara, Turkey. (Unpublished Master Thesis).

Hong, E. (1999). Preffered and actual homework style: A cross cultural examination. Educational Research Journal, 41(3), 251-265.

İnal, U. (2009). Examining perception of teachers and students at elementary boarding district school in borders of Adana province with respect to the quality of school life. Çukurova University Institute of Social Sciences, Adana, Turkey. (Unpublished Master Thesis).

Kazu, İ. Y. \& Aşkın, Z. (2011). The problems faced in study periods and in leisure-time activities at regional boarding primary education schools: A case study of Elazı̆̆. Pegem Journal of Education and Instruction, 1(3), 39-46.

Kırılmazkaya, G., Keçeci, G. \& Kırbağ Zengin, F. (2011, Mayıs). The detection of elementary students' uses information and communication technologies for performance tasks in science and technology course. International Advanced Technologies Symposium, 16-18 May, Elazı̆̆g, Turkey.

Kumandaş, H. \& Kutlu, Ö. (2010). The factors affecting $5^{\text {th }}$ grade students' attitudes towards performance tasks. Elementary Education Online, 9(2), 714-722.

Küçük, Y. \& Arıkan D. (2005). The determination of the hopelessness levels of children with hearing impaired. International Journal of Human Sciences. 2(2), 1-13.

Lucia, R. C. S., Gesten, E., Rendina-Gobioff, G., Epstein, M., Kaufmann, D., Salcedo, O. (2000). Children's school adjustment: A developmental transactional systems perspective. Journal of Applied Developmental Psychology, 21(4), 429-446.

MEB (2003).Yatılı ilköğretim bölge okulları ve pansiyonlu ilköğretim okulları yönetici kılavuz kitabı. Milli Eğitim Basımevi, İstanbul, Türkiye. [Ministry of Education, Administrator 
Guide Book about Boarding and Pensioned Primary Schools, National Education Publishing, İstanbul Turkey.]

MEB (2004). İlköğretim Fen ve Teknoloji Dersi Öğretim Programı. Talim ve Terbiye Kurulu Başkanlığ 1 , Ankara. [Ministry of Education, Elementary Science and Technology Curriculum. Head of Instruction and Education Board, Ankara, Turkey.]

Resmi Gazete (2012). Millî Eğitim Bakanlığı İlköğretim Kurumları Yönetmeliğinde Değişiklik Yapılmasına Dair Yönetmelik. No: 28360.[Official Gazette, Ministry of National Education, Amending the Primary Schools Regulation, No: 28360].

Öztürk, P. (2010). The evaluation of relation between success grades of Turkish lesson performance task and academic success and attitude to lesson in primary education school level. Karadeniz Teknik University Institute of Social Sciences, Trabzon, Turkey. (Unpublished Master Thesis).

Pekdemir, Z. \& Akyol, A. (2011). An analysis of multiple intelligence domains of 5th grade students attending different primary schools. Journal of Theoretical Educational Science, 4(1), 154-163.

Pettit, G. S., Bates, J. E. \& Dodge, K. A. (1997). Supportive parenting, ecological context, and children's adjustment: a seven-year longitudinal study. Child Development,68, 908-923.

Secer, M. (2010). Primary school teachers' and students' opinions about performance assignments and using internet on preparing performance assignments. Mersin University Institute of Social Sciences, Mersin, Turkey. (Unpublished Master Thesis).

Şenol, D. \& Y1ldız, S. (2009). Student-Teacher and family interaction in the boarding primary teaching regional schools: The cases of Diyarbakir and Erzurum. Journal of Çukurova University Institute of Social Sciences, 18(1), 359-376.

Udum, C. (2012). Review of students' achievement levels in Maths tests of SBS exam between General primary schools and Boarding region primary schools. Firat University Institute of Educational Sciences, Elazığg, Turkey. (Unpublished Master Thesis).

Uzoğlu, M., Öztürk, P., Bülbül, E. \& Küçükaydın, Z. (2013). The effect on students' academic success of performance duty in science and technology course. International Journal of Social Science, 6 (1), 1495-1509.

Wentzel, K. R. (1997). Student motivation in middle school: the role of perceived pedagogical caring. Journal of Educational Psychology, 89 (3), 411-419.

Yeşilyurt, S. (2006). A study on high school students' attitudes towards Biology assignments. Journal of Erzincan Educational Faculty. (8), (1), 37-53.

Y1lmaz, B. \& Benli, N. (2011). The evaluation of performance tasks given at the first degree of primary education according to teachers' opinions. Dokuz Eylül University Journal of Buca Faculty of Education, 30, 250-265. 